\title{
Municipal Solid Waste Management Problems on a Local Scale: A Case Study from Rural Poland
}

\author{
Andrzej Macias*, Witold Piniarski \\ Adam Mickiewicz University, Faculty of Geographical and Geological Sciences, \\ Institute of Physical Geography and Environmental Planning, Department of Landscape Ecology \\ Dziegielowa 27, 61-810 Poznań, Poland
}

Received: 26 May 2015

Accepted: 8 March 2016

\begin{abstract}
Our paper presents problems of local waste management systems in Poland using the example of the environmentally valuable area of Pobiedziska urban-rural commune, which has serious problems with municipal waste management. Right now, illegal waste sites are common all over this precious area due to low ecological awareness by the inhabitants.

We will show problems caused by the previous waste management system (until 1 July 2013) in comparison with the current, recently introduced waste management system. Illegal dumping sites together with local ignorance remain the hot issue within the local waste management system in Pobiedziska urban-rural commune.
\end{abstract}

Keywords: waste management, waste structure, local waste management system, Pobiedziska urbanrural commune

\section{Introduction}

One of the main environmental problems in Poland that remains to be solved is municipal solid waste management. It is municipalities' responsibility to carry out the principles and objectives of the National Waste Management Plan and the Voivodship Waste Management Plan, since the municipalities (urban areas) are local government units of basic importance [1]. The organization of the local waste management system comes under municipality authority [2-5].
Until 2013 not all inhabitants were included in the system of waste management. This situation resulted in many examples of improper waste disposal, such as burning garbage in households or disposing of waste outside waste disposal sites. At present, the local system of waste management has completely changed and all inhabitants now participate in waste collection; also, waste segregation has increased in importance [2, 6-8]. The objective was to introduce the most effective system of waste management where few facilities can successfully handle waste from quite a large area (a few urban districts). This has led to many changes at the local level [9].

Local systems of waste management have been poorly researched so far. Most research in the field has concentrated on theoretical, legal, and technical issues

*e-mail: macias@amu.edu.pl 
e.g., waste disposal methods; [10-21] rather than on environmental and social effects [22-30] as well as environmental threat assessments and irregularities in local waste management systems. All these aspects are of great importance, especially where protected natural areas are concerned.

Until now, the most common method of waste management in Poland has been landfill deposition [2-3, 12]. Inhabitants' low awareness of the ecological aspects of rational waste management is another problem, although according to a survey by Nycz-Wróbel [31], respondents have strong awareness that waste disposal is one of the greatest threats to the natural environment.

The aim of this paper is to assess the local system of waste management before and after new legal solutions were introduced, to identify irregularities in the system and to analyze social awareness concerning local waste management using the example of the town of Pobiedziska and its rural commune. The results will serve as comparison material to assess the effectiveness of a new system of waste management.

\section{Data and Methods}

The source of data used to assess the local system of waste management was fieldwork as well as the data from strategic documents of companies operating in the field of waste management in and around Pobiedziska. Documents received from the Pobiedziska Urban-Rural Commune Administration Office were also used. Results of the survey carried out among inhabitants of the study area were also taken into account. One-hundred and seventyfive respondents took part in the survey (almost $1 \%$ of the population of the territorial unit) from seven locations (including Pobiedziska and the following villages: Letnisko Leśne, Biskupice, Jerzykowo, Wronczyn, Węglewo, and Pomarzanowice). These are villages from the western (mostly urban) part of the municipality as well as villages from its eastern part, where rural areas dominate. The respondents were adults of different ages, genders, and levels of education. The specific choice of villages and urban centers, as well as taking into account educational levels and genders of all respondents in the survey, was made in order to reflect the social structure of local society as much as possible. A survey among almost $1 \%$ of the total population under some extra conditions can provide a very precise model of local society. Keeping major characteristics and certain proportions of this structure during sampling and the surveying process, as well as keeping proper spatial distribution and dispersion of the Pobiedziska urban area inhabitants, was one of the most important elements of all research [32]. The key goal was to determine the approach of the local community toward vast changes that are to be introduced in the system of waste management in the urban area. The survey aimed at identifying the level of ecological awareness among local inhabitants and establishing their opinions on local waste management. It also was important to get to know which problems relating to waste management are recognized by the community.

The fieldwork focused on inventorying illegal waste dumping sites and recycling banks. A $350 \mathrm{~km}$ route was analyzed in relation to locating, characterizing, and measuring illegal dumping sites. The locations and compositions of recycling banks were verified and compared with the data acquired from Municipal Services Company in Pobiedziska. In the process of inventory the geolocation techniques were used with the help of a GPS system. Detailed photographic documentation was also collected. For each identified illegal waste dumping site an inventory card was created, which provides us with information about locations in geographic space (Geoportal maps and aerial photos were used) as well as physical and geographical characteristics of the site, the size of a site (surface area, volume), waste site composition (fractions in the waste), the present state of a site (if it is used, to what extent; or if not used, for how long).

In order to visualize fieldwork results we used an electronic map generated at 1:50,000 scale with the help of GIS techniques on the basis of a vector map of level 2 (VMAP2).

\section{Study Area}

The chosen study area was the town of Pobiedziska, which includes the Pobiedziska rural area within the present administrative limits. It covers an area of $189 \mathrm{~km}^{2}$, $10 \mathrm{~km}^{2}$ of which are occupied by Pobiedziska proper. The study area is situated in Wielkopolska Province and constitutes the largest urban district of Poznań County. Although it is not adjacent to Poznań, Pobiedziska urbanrural commune is numbered among administrative units constituting the Poznan agglomeration. As of 2011, the commune's population was 8,997 . There is one town within the commune: Pobiedziska and 55 villages [33].

Pobiedziska urban-rural commune is counted among environmentally valuable areas with numerous legal forms of environmental protection, including four nature reserves of importance for landscape, forest, and flora. In addition, the study area lies within the borders of three landscape parks, including Puszcza Zielonka Landscape Park, which is a part of the Natura 2000 network. There are numerous individual forms of environmental conservation (69 nature monuments), and protected areas cover almost one-fifth of the studied administrative unit area (19.5\%).

In order to implement an effective waste management system, Pobiedziska has acceded to the Poznań Agglomeration Waste Management Inter-Municipal Association (ZM GOAP). ZM GOAP, in terms of area, consists of 23 sectors, one of which covers Pobiedziska and Pobiedziska rural commune. At present, the municipal infrastructure of Pobiedziska urban-rural commune includes one landfill situated in Borówko village, which is a property of the Pobiedziska Urban-Rural Commune Administration Office. Municipal waste only from the Pobiedziska urban-rural commune area (wastes other than hazardous and inert waste) is deposited there [34]. 
Table 1. Individual waste collection rates per person per year.

\begin{tabular}{|c|c|c|c|c|c|c|c|c|c|c|}
\hline \multicolumn{2}{|c|}{ Detailed list } & $\mathbf{2 0 0 4}$ & $\mathbf{2 0 0 5}$ & $\mathbf{2 0 0 6}$ & $\mathbf{2 0 0 7}$ & $\mathbf{2 0 0 8}$ & $\mathbf{2 0 0 9}$ & $\mathbf{2 0 1 0}$ & $\mathbf{2 0 1 1}$ & $\mathbf{2 0 1 2}$ \\
\hline \multirow{4}{*}{\begin{tabular}{c} 
Waste collected \\
\cline { 2 - 10 }
\end{tabular}} & Pielkopolska province & 298.0 & 255.9 & 265.8 & 255.8 & 262.1 & 263.8 & 268.0 & 269.0 & 270.0 \\
\cline { 2 - 10 } & Pobiedziska & 418.9 & 408.6 & 454.7 & 420.1 & 412.5 & 431.2 & 399.9 & 362.7 & 359.5 \\
\hline \multirow{3}{*}{$\begin{array}{c}\text { Waste collected from } \\
\text { households }\end{array}$} & Poland & 177.3 & 170.2 & 180.6 & 184.7 & 180.5 & 181.0 & 180.6 & 179.0 & 177.0 \\
\cline { 2 - 10 } & Wielkopolska province & 208.0 & 182.7 & 184.1 & 180.7 & 178.7 & 183.6 & 188.5 & 191.0 & 190.6 \\
\cline { 2 - 10 } & Pobiedziska & & 290.8 & 328.6 & 320.0 & 322.4 & 284.9 & 272.3 & 274.2 & 278.3 \\
\hline
\end{tabular}

Source: compiled on the basis of [35-37].

\section{Results and Discussion}

The local waste management scheme until 2013 was based on collecting unsorted (mixed) waste and sorting the waste into fractions using recycling containers. The main method of waste disposal was waste deposition. However, since 1 July 2013 a new so-called "bag collection system" was applied, which entails local property owners collecting and segregating their own mixed waste into specially marked bags. Residents receive these bags from the company that handles municipal waste in the commune. The aim was to increase the level of recovery of selected fractions of municipal waste and reducing the household waste stream going into the landfill.

\section{The Structure of the Municipal Waste Stream and the Degree of Waste Recovery}

The qualitative and quantitative structure of waste is an extremely important issue in the local waste management system. Table 1 shows the quantitative structure of waste generated in 2012-14 in comparison with data from Wielkopolska Province and national data. There are much higher individual municipal waste generation rates in the analyzed municipality than in the province and the country, when compared either with the forecasted rates [2] or the assumed rates in the National Waste Management Plan 2014 [35] (354 kilos per person with respect to waste generated, not collected). The same discrepancy is observed in the quantity of all municipal waste collected compared to household waste collected. This is probably the result of tourists using recreational housing areas. There are 2,000 summer cabins located within the analyzed area (most near Zalew Kowalskie). Holidaymakers significantly influence the municipal waste stream, including waste collected in a selective manner (recycling bins have been introduced into the recreational areas).

Table 2 presents selected basic information about the waste management system in the analyzed area. It can be noted that the amount of municipal waste has varied significantly over the years (for example the difference

Table 2. Selected elements of waste management in the Pobiedziska urban district.

\begin{tabular}{|c|c|c|c|c|c|c|c|}
\hline Rates & 2004 & 2005 & 2006 & 2007 & 2008 & 2009 & 2010 \\
\hline $\begin{array}{l}\text { Quantity of municipal solid waste collected } \\
{[\mathrm{Mg} / \text { year }]}\end{array}$ & $6,677.50$ & $6,625.79$ & $7,486.56$ & $7,098.70$ & $7,098.70$ & $7,581.25$ & $7,244.70$ \\
\hline Household waste $[\mathrm{Mg} /$ year] & & $4,678.70$ & $5,382.80$ & $5,308.91$ & $5,506.87$ & $4,958.03$ & $4,892.59$ \\
\hline $\begin{array}{c}\text { The share of municipal waste in waste } \\
\text { deposited in landfills [\%] }\end{array}$ & 82.45 & & 81.90 & 76.71 & 78.55 & 90.32 & 88.94 \\
\hline $\begin{array}{c}\text { The share of raw material recovery in } \\
\text { municipal waste stream [\%] }\end{array}$ & 1.61 & & 1.83 & 2.37 & 3.28 & 3.86 & 4.30 \\
\hline Quantity of recyclables $[\mathrm{Mg}]$ & 107.36 & & 137.34 & 168.00 & 232.58 & 292.74 & 311.56 \\
\hline $\begin{array}{l}\text { Quantity of problematic waste }[\mathrm{Mg}] \\
\text { including: }\end{array}$ & $2,182.06$ & & $2,726.08$ & $4,582.19$ & $3,355.87$ & $1,923.06$ & 762.28 \\
\hline - large-size waste $[\mathrm{Mg}]$ & 0 & & 2.16 & 9.42 & 38.06 & 65.14 & 70.98 \\
\hline - construction waste $[\mathrm{Mg}]$ & $2,182.06$ & & $2,723.85$ & $4,569.89$ & $3,313.95$ & $1,810.27$ & 656.12 \\
\hline - hazardous waste $[\mathrm{Mg}]$ & 0 & & 0.07 & 2.89 & 3.86 & 0.1 & 0.18 \\
\hline - waste containing asbestos $[\mathrm{Mg}]$ & 18.2 & & 18.2 & 26.67 & 55.09 & 34.56 & 24.07 \\
\hline
\end{tabular}

Source: compiled on the basis of [36-37]. 
between 2009 and 2011 is more than 900 tons), which is probably connected with the number of holidaymakers in individual years. Greater stability is observed in the amount of collected household waste (with the exception of 2008-09 with a difference of 500 tons). Generally, up to 2010 the situation in the analyzed area as far as local waste management is concerned is typical of Poland, i.e., only a small part of the waste stream is recycled (1.6-4.3\%; there's a growing tendency) and storage in waste landfills is the dominant method of waste disposal (municipal waste accounted for $77-90 \%$ of waste stored).

Problematic waste, including hazardous waste, remains a hot issue within the local waste management system. In the analyzed commune (like in many other communes), such waste, given its problematic nature, is collected according to a different scheme.

In the analyzed area the share of large-size waste has systematically increased over the course of 2004-10, from 2.16 Mg to $70.98 \mathrm{Mg}$ in 2010 (Table 2) - a 30-fold increase. On the other hand, the quantity of construction waste is directly connected with the amount of construction work in the commune. A substantial increase in construction waste collected in 2007-08 was caused by numerous instances of repair and construction work carried out within the territory of the commune in question (mainly expansion, repair, and thermomodernization of the buildings owned by the local government, including schools and the municipal office building [38]). A large decrease in construction waste collected was noted when all the above-mentioned work came to an end. It can be concluded that Pobiedziska residents are not interested in proper disposal or management of this kind of waste. Construction waste collection and its transportation are problematic and costly, which is another part of the problem (the landfill site in Borówko village charges an additional fee for construction waste). As a result, construction waste is often collected as mixed waste or is deposited in illegal dumping sites.

Hazardous waste is an exceptional problem. Taking data shown in Fig. 2 into account, it can be noted that, similarly to construction waste, hazardous waste increased in 2007-08. This is also due to repair and construction

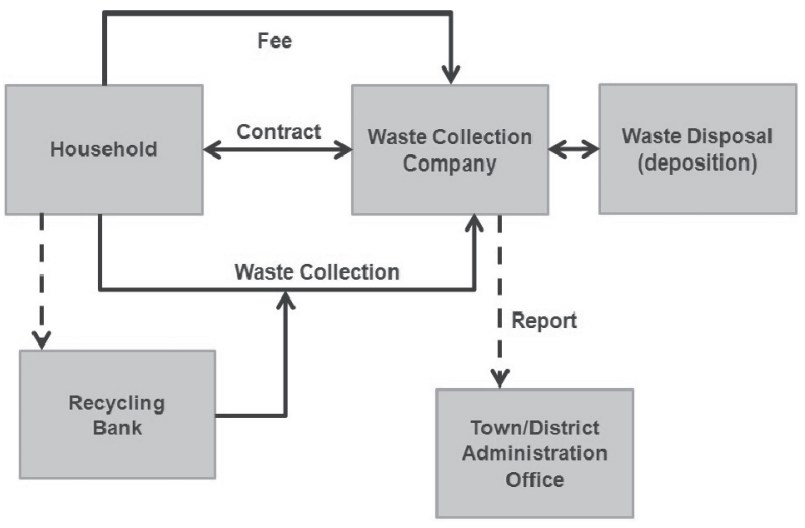

Fig. 1. The waste management system in the Pobiedziska urban district through 2013. work. In general, the quantity of hazardous waste collected is too small when the individual rate $(2 \mathrm{~kg} /$ person $)$ is taken into account [35]. It can be estimated that the municipality generates between $31.9 \mathrm{Mg}$ (2004) and $37.2 \mathrm{Mg}$ of various types of hazardous waste. The real problem is what happens with this type of waste and in what way it is disposed of. It's likely that this kind of waste is part of a mixed waste stream that is deposited in Borówko landfill.

As far as other kinds of hazardous waste are concerned, it is collected and deposited in special, separate areas within Borówko landfill. In 2009 the following quantities of hazardous waste were collected: $23.97 \mathrm{Mg}$ of electrical and electronic equipment, $20.96 \mathrm{Mg}$ of end-of-life tires, and $2.62 \mathrm{Mg}$ of tar paper. A year later (2010), the quantity was $13.9 \mathrm{Mg}$ of electrical and electronic equipment, $18.18 \mathrm{Mg}$ of end-of-life tires, and 2.92 Mg tar paper.

Another problematic question concerning hazardous waste is the disposal of construction waste - including construction materials containing asbestos, such as concrete roof panels. In the analyzed municipality we found from 18.2 Mg (2006) to $55.1 \mathrm{Mg}$ (2008) of such construction waste disposed of, and in 2013 the numbers included $83.16 \mathrm{Mg}$ of concrete roof panels containing asbestos. The 2014 inventory revealed about 2,700 Mg of waste containing asbestos [39].

Tendencies in quantitative and qualitative changes in waste management within our study area show great diversity. The total quantity of municipal solid waste collected varies widely and it is impossible to identify a clear trend. Loads of municipal solid waste are mainly deposited in the landfill site in Borówko, and according to waste management hierarchy [40-41], landfill deposition is the worst solution with the lowest share of resource recovery in the total municipal waste stream.

Throughout 2004 and 2006-11, the total amount of recyclables collected in the study area increased systematically (Table 3). However, the rate of waste collected in a selective manner in the analyzed municipality is generally lower than the national and provincial averages. When the individual fractions of waste collected in a selective manner are investigated, only individual glass collection rates are higher than those noted on national and provincial levels. As far as waste paper is concerned, the individual rate in the examined commune is higher than the national one, but lower than the provincial one. This is probably the impact of tourists summering in the study area. Compared with individual waste generation rates, the rate of waste collected in a selective manner (Table 4) is very low. Most recyclable waste is either collected as mixed waste or burned in household hearths (waste paper and plastics). Only metal waste, due to its monetary value, is almost $100 \%$ recovered, even from mixed waste, by scrap-metal collectors who sell it to scrapyards.

The new system solutions in waste management introduced in mid-2013 (known in Poland as the "waste revolution") have contributed to a significant improvement in the size of the recovery of selected fractions of municipal waste. In fact, data from the analyzed commune shows that the amount of waste going to a landfill gradually begins 
Table 3. Rates of selective waste collection (kg per inhabitant).

\begin{tabular}{|c|c|c|c|c|c|c|c|c|}
\hline \multicolumn{2}{|c|}{ Detailed list } & 2004 & 2005 & 2006 & 2007 & 2008 & 2009 & 2010 \\
\hline \multirow{3}{*}{ Total, including: } & Poland & 6.37 & 7.78 & 10.57 & 9.05 & 17.88 & 20.67 & 22.51 \\
\hline & Wielkopolska province & 7.43 & 8.90 & 14.50 & 10.63 & 23.25 & 26.11 & 27.49 \\
\hline & Pobiedziska & 6.73 & & 8.34 & 9.94 & 13.51 & 16.65 & 17.20 \\
\hline \multirow{3}{*}{ Paper and cardboard } & Poland & 1.76 & 2.52 & 2.62 & 2.94 & 3.80 & 3.96 & 4.45 \\
\hline & Wielkopolska province & 2.67 & 3.26 & 5.03 & 2.66 & 6.48 & 7.33 & 7.31 \\
\hline & Pobiedziska & 1.71 & & 2.25 & 3.14 & 4.36 & 5.51 & 4.85 \\
\hline \multirow{3}{*}{ Glass } & Poland & 1.91 & 2.59 & 2.99 & 3.57 & 4.59 & 5.24 & 5.65 \\
\hline & Wielkopolska province & 3.27 & 3.56 & 5.03 & 4.13 & 6.77 & 7.04 & 8.19 \\
\hline & Pobiedziska & 3.62 & & 4.52 & 5.22 & 6.97 & 9.12 & 9.50 \\
\hline \multirow{3}{*}{ Plastics } & Poland & 0.81 & 1.07 & 1.44 & 1.76 & 2.18 & 2.62 & 3.25 \\
\hline & Wielkopolska province & 1.19 & 1.78 & 2.37 & 1.77 & 3.53 & 3.81 & 4.68 \\
\hline & Pobiedziska & 1.39 & & 1.35 & 1.43 & 2.01 & 1.89 & 2.14 \\
\hline \multirow{3}{*}{ Metals } & Poland & 0.26 & 0.18 & 0.18 & 0.18 & 0.24 & 0.37 & 0.45 \\
\hline & Wielkopolska province & 0.30 & 0.30 & 0.30 & 0.00 & 0.29 & 0.88 & 0.59 \\
\hline & Pobiedziska & 0.00 & & 0.09 & 0.15 & 0.17 & 0.14 & 0.00 \\
\hline \multirow{3}{*}{ Large-size waste } & Poland & 1.26 & 0.89 & 1.1 & 1.89 & 2.54 & 2.41 & 2.70 \\
\hline & Wielkopolska province & 0.30 & 0.30 & 0.30 & 0.59 & 1.18 & 1.47 & 1.17 \\
\hline & Pobiedziska & 0 & & 0.13 & 0.56 & 2.21 & 3.71 & 3.92 \\
\hline
\end{tabular}

Source: developed on the basis of data from [35-37, 46].

to decrease, and the amount of recycled waste increases. This tendency is easily observed when data concerning collected plastic in the analyzed commune is taken into account (Table 5); additionally, plastic waste is a desirable recyclable material for the still-developing system of waste utilization in Poland [42]. In 2012-14 the amount of recycled plastics in this municipality almost doubled.

As stated before, the total amount of waste collected in a selective manner is disproportionate to the total municipal solid waste generated and collected, which constitutes a crucial economic and environmental problem.

Table 4. Rates used to estimate different waste streams.

\begin{tabular}{|c|c|c|}
\hline \multirow{2}{*}{ Type of waste } & \multicolumn{2}{|c|}{$\begin{array}{c}\text { Individual waste generation rate } \\
\text { (kilo per person) }\end{array}$} \\
\cline { 2 - 3 } & small towns & rural areas \\
\hline Paper and cardboard & 34 & 12 \\
\hline Glass & 36 & 24 \\
\hline Plastics & 39 & 25 \\
\hline Metals & 5 & 6 \\
\hline Large-size waste & 9 & 3 \\
\hline
\end{tabular}

Source: [35]
In order to use waste as recyclables it is necessary to sort waste according to its type. This enables the recovery of useful materials and allows recyclable materials to be reused in production. Waste sorting helps to reduce the natural resource extraction and is both economically and environmentally advantageous, since resource recovery is cheaper than withdrawal of resources from nature. Furthermore, the quality of the natural environment is improved. For all the above-mentioned advantages to occur, waste sorting is fundamental, and the cheapest and most effective form is sorting at the point of origin.

\section{Mixed and Sorted Waste Collection System}

The previous waste management system (legally binding until 1 July 2013) did not attach significance to waste segregation. The main method of waste disposal was its deposition. Owners of the properties signed contracts not with the administration office, but with the waste collection company (Fig. 1), so there was no control over whether all inhabitants were provided with collection services. The Pobiedziska Urban-Rural Commune Administration Office claims that $100 \%$ of inhabitants were included in waste collection, yet the amount of waste generated compared with the amount of waste collected and deposited as well as the number of illegal waste dumping sites implies that not all waste was 
Table 5. The amount of collected plastics in the Pobiedziska urban district in 2003-14.

\begin{tabular}{|c|c|c|c|c|c|c|c|c|c|c|c|c|}
\hline Year & $\mathbf{2 0 0 3}$ & $\mathbf{2 0 0 4}$ & $\mathbf{2 0 0 5}$ & $\mathbf{2 0 0 6}$ & $\mathbf{2 0 0 7}$ & $\mathbf{2 0 0 8}$ & $\mathbf{2 0 0 9}$ & $\mathbf{2 0 1 0}$ & $\mathbf{2 0 1 1}$ & $\mathbf{2 0 1 2}$ & $\mathbf{2 0 1 3}$ & $\mathbf{2 0 1 4}$ \\
\hline $\begin{array}{c}\text { Amount } \\
{[\mathrm{Mg}]}\end{array}$ & 17.43 & 22.13 & & 22.22 & 24.22 & 34.60 & 33.16 & 38.68 & 48.10 & 60.52 & 86.60 & 109.80 \\
\hline
\end{tabular}

Source: developed on the basis of data from the Municipal Council Office in Pobiedziska.

collected in an organized manner. Moreover, only $80 \%$ of Poland's citizens have contracts for municipal solid waste collection.

A major local waste management problem is connected with recreational housing areas in this commune. There are numerous plots with summer cabins that form a compact settlement. In this case, before 2013 there was no waste segregation as waste was collected in bulk containers. After 2013, containers for collecting segregated and mixed waste were introduced. The set of containers often includes an additional container for green waste (e.g., grass and branches).

Selective waste collection within the study area by mid-2013 was carried out based on recycling banks. A recycling bank consists of $1.5-\mathrm{m}^{3}$ recycling bins that are used to collect different municipal wastes. There are 66 recycling banks within the Pobiedziska commune area, 18 of which are located in Pobiedziska proper. Every fourth recycling bank includes a separate container for secondhand clothing donations, for a total of 12 altogether in the study area. Every fifth recycling bank (16 in total) collects grass (bio waste). Locations and composition of the recycling banks are shown in Fig. 2. But it is not an optimal system, given the low amounts of waste collected this way.

Hence, from 1 July 2013 the method of collecting at source was introduced. Due to a large number of visitors, the method based on recycling banks was introduced to complement the first method.

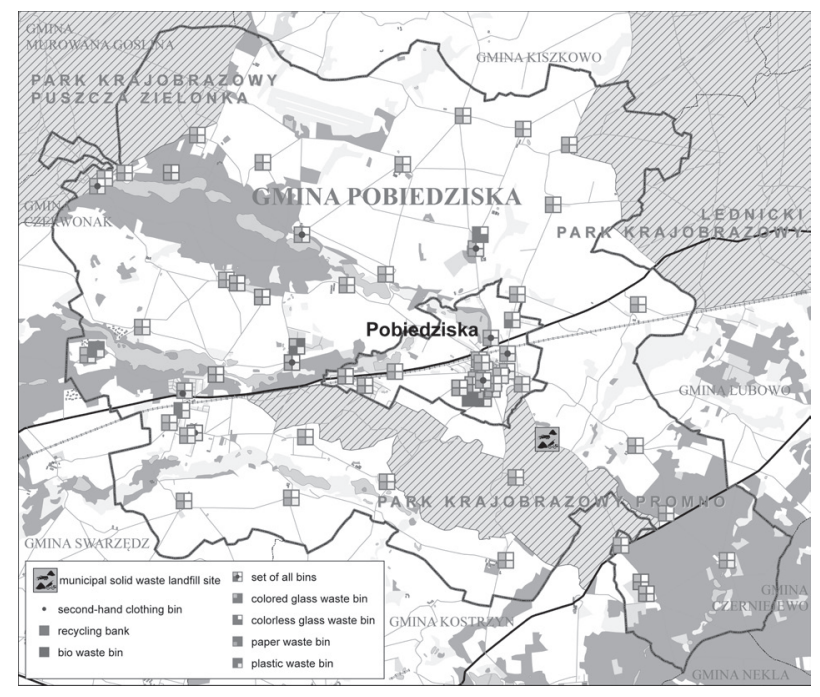

Fig. 2. Locations of recycling banks within Pobiedziska urban district.
Batteries are also collected separately in special containers in the Pobiedziska Urban-Rural Commune Administration Office, the Municipal Services Department in Pobiedziska, and in all educational institutions within the commune [43]. All types of batteries can also be transferred directly to Borówko landfill site (no fee charged), where they are collected in special containers. Large items, electrical and electronic equipment, fluorescent lamps, car batteries, and hazardous packaging agents are collected from households every six months.

The 2011 inventory revealed 107 illegal waste disposal sites located across a total area of $2,765 \mathrm{~m}^{2}$ with as much as $498.2 \mathrm{~m}^{3}$ waste (ca. $84 \mathrm{Mg}$ ). The local authorities are currently trying to eliminate illegal dumping sites (Table 6). When they are found, all waste from illegal dumping sites is collected and taken to the landfill site in Borówko, where the process of recycling or neutralizing is implemented.

The reasons for this state should be looked for in the low level of ecological awareness of inhabitants and visitors, as well as not entirely well-functioning local waste management system which, until mid-2013, did not include all residents - let alone visitors. The discussed situation also resulted from the fact that a basic system of waste collection was based on single mixed municipal waste containers. In this system, the fee for waste collection depended on the declared capacity and number of containers. This was conducive to improper handling of waste and contributed greatly to the intensification of the problem of illegal dumps.

It can be concluded that the solid municipal waste collection system within the analyzed area was not very efficient. As a result, numerous illegal waste dumping sites existed, a small amount of waste was segregated, and the main method of waste disposal was waste deposition. It had nothing to do with the waste management hierarchy recommended in the Waste Framework Directive [40]. After 2013, when this directory was implemented, the local waste management system was changed (Fig. 3). It is too early, though, to assess its efficiency and impact on the natural environment.

\section{Waste Disposal in the Study Area}

The total area of the waste landfill site in Borówko is 4.6 ha. Currently, section 1 of 1.308 ha and a capacity of $101,500 \mathrm{~m}^{3}$ is used. The problem, however, is that it is already $90 \%$ full. There is also an unused section 2 with an area of 1.16 ha [44]. Initially, section 1 was to be used for a period of 11.5 years (from 1996 to mid-2007). After filling section 1, waste was to be disposed of in the 
Table 6. Summary of liquidated illegal dumps in Pobiedziska municipality 2009-15.

\begin{tabular}{|c|c|c|c|c|c|c|c|}
\hline Year & $\mathbf{2 0 0 9}$ & $\mathbf{2 0 1 0}$ & $\mathbf{2 0 1 1}$ & $\mathbf{2 0 1 2}$ & $\mathbf{2 0 1 3}$ & $\mathbf{2 0 1 4}$ & $\mathbf{2 0 1 5}$ \\
\hline $\begin{array}{c}\text { Number of liquidated of illegal dumps } \\
{[\mathrm{pcs}]}\end{array}$ & 12 & 2 & 11 & 12 & 10 & 15 & $24^{*}$ \\
\hline \begin{tabular}{c} 
The amount of waste collected $[\mathrm{Mg}]$ \\
\hline
\end{tabular} & 22.9 & 0.7 & 14.6 & 39.8 & 15.9 & 20.3 & $55.6^{*}$ \\
\hline
\end{tabular}

* data from the first half of 2015

Source: developed on the basis of data from the Municipal Council Office in Pobiedziska.

landfill by opening section 2, which in turn was planned to be exploited by less than a decade, until 2017. Then the space between the two heaps was to be used, which would provide a further 18 months of continuous operation of the landfill site. The total exploitation time of the site was planned for the years 1996-2018, which accounts for 22.5 years of non-stop operation. It was predicted that nearly $200,000 \mathrm{~m}^{3}$ of waste would be collected [45]. Recently, however, the plans were modified considerably due to the membership of the Pobiedziska municipality in ZM GOAP. The operating time of section 1 is being extended to the maximum, because contrary to previous forecasts there are no plans for section 2 to be used, even though it still serves as the landfill backup. Under the Wielkopolska Voivodship Waste Management Programme 2012-17 [46], the waste landfill in Pobiedziska has a status of a substitute system and shall be used "until regional systems for communal waste processing are initiated" [41].

Only mixed waste (other than hazardous and inert waste) is neutralized in Borówko landfill. The section has no special sector for hazardous waste disposal. The landfill operation area coincides with the Pobiedziska urban-rural commune, which allows for better evaluation of the local waste management system.

When analyzing the total size of the stream of mixed municipal waste going into the Borówko landfill before and after 1 July 2013, attention should be paid to the significant reduction over the years. In 2011 a total of 7,042.9 $\mathrm{Mg}$ of mixed waste went into landfill, in 2013

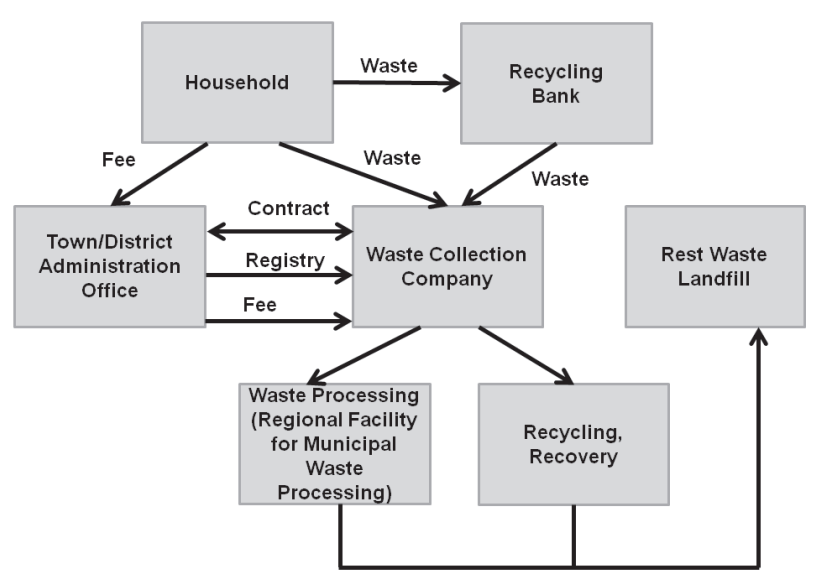

Fig. 3. The new local waste management system implemented in 2013. it was a smaller but comparable amount of $6,978.6 \mathrm{Mg}$. In 2013, when the changes resulting from the "waste revolution" were introduced, there was a significant decrease in the size of the household waste stream deposited in the municipal landfill $(6,255.5 \mathrm{Mg}$ of deposited waste). Year 2014 was the first year when a new system operated and another drop in the amount of mixed waste stored in a municipal landfill in the village of Borówko was noted, as in 2014 it was $5,906.5 \mathrm{Mg}$. A similar trend was noticed in the first half of 2015 (until the end of June 2015 it was $2,964.2 \mathrm{Mg}$ of mixed waste deposited in the landfill in Borówko, and it is estimated that the trend will be consistent in the second half of 2015). It can be concluded that the systemic changes in terms of local waste management introduced after July 1, 2013 in the study area produced tangible results in the form of a substantial reduction in the amount of mixed waste disposed of in the landfill site. There was a $15 \%$ reduction in the amount of mixed waste deposited in the landfill in Borówko between 2012 (the year preceding the changes) and 2014 (the first full year when the new system operated).

This landfill site creates many environmental problems, e.g., odor emissions or periodic microbial air contamination. Its highest concentration is in spring and summer [47]. There is also a real danger of water pollution. The site is systematically monitored in terms of potential underground water pollution (six piezometers installed). It is located on the area of GZWP (the main groundwater body) No. 144, Wielkopolska Dolina Kopalna, and borders on the artificial water body formed on a mining exploitation hollow. So far there has been no evidence of direct impact of the landfill on groundwater pollution, separated from the ground by geomembrane. The emission level and the composition of landfill gas is also monitored [48]. The degassing network consists of six wells. The landfill is degassed passively and the produced biogas is not used economically.

\section{Ecological Awareness of Local Residents}

We conducted a survey in order to determine the level of ecological awareness in terms of waste management. A sample of $1 \%$ of the local residents was interviewed. The survey did not include the temporary population residing in recreational housing areas. An important indicator of the problem is the share of people who segregate waste. According to the survey responses, three quarters of those polled declare that they collect waste in a selective manner. Although a high number 
of people claim to sort their waste, interestingly enough this is not reflected in the actual amount of waste collected. However, taking into account the fact that more than $50 \%$ of respondents had a university degree, it can be assumed that residents' answers had more to do with knowledge of how to sort or readiness to do so rather than actual practice. Still, it is a positive signal with reference to a possible new waste sorting system. The survey also revealed that people segregate some groups of waste but not everybody segregates all groups, e.g., nearly three quarters of inhabitants segregate glass and plastic but only every fifth of them separately collects organic waste. The issue of segregating biodegradable waste is problematic not only to this municipality but also to all other local government units and the whole country.

In the case of residents who do not collect segregated waste, the most frequent cause is uncertainty about how the segregated waste is managed. This results from the fact that on many occasions segregated waste reportedly was being remixed when municipal services took it to the landfill site. If these observations are true it would mean that there were irregularities in operations of services authorized by the municipality to collect segregated waste within the study area. Another reason why every $10^{\text {th }}$ person does not segregate waste is difficult access to recycling banks, which is a fundamental element of the selective waste management system. According to $8.6 \%$ of those polled, selective waste containers near their houses are also problematic as they are constantly overloaded. Similarly, $8.6 \%$ of respondents say that the reason they do not segregate waste is insufficient space for separate containers in their households. It is highly probable that providing inhabitants with better access to recycling banks would increase their number, as well as emptying the existing ones more often. This is confirmed by the fact that less than $2 \%$ of all respondents regard waste segregation as unnecessary and a little more than $1 \%$ has no knowledge of waste segregation principles. This group of inhabitants could be supported with proper information or a promotional campaign, on the benefits of waste segregation. Unfortunately, the authorities of Pobiedziska show no sign of such ideas. The only information addressed to inhabitants in terms of waste management is included in a monthly "Biuletyn Pobiedziski" published by the Pobiedziska Urban-Rural Commune Administration Office. It usually includes fragmentary pieces of information about waste segregation or waste collection fees; the articles are incidental with little information - definitely not a large-scale campaign. Only schools of the Pobiedziska urban-rural commune-run ecological education programs deal with the issue to some extent, e.g., Earth Day or "Clean Up the World," when pupils from local schools collect garbage scattered across the town. The only open initiative that is addressed not only to children but also to adults and families is the local edition of "National Educational Ecological Picnic" that has been organized since 2009. It promotes ecological attitudes of the residents of the Pobiedziska urban-rural commune who take part in the event [44]. The fact remains, however, that a quarter of all responses indicates that inhabitants should be much better informed in terms of the waste management system.

Another problem pointed out by residents is waste collection fees or concerns of new rates to be introduced as of 1 July 2013 (the survey was held directly before setting the new rates). The concerns turned out to be partly justified. Fees were considerably increased for mixed waste collection, yet for segregation by minimum four-person families, the costs could even be lower than before. This means that irrespective of the amount of waste produced in a household, the fee for collection and further management shall stay unchanged, which should reduce or even eliminate the use of illegal dumping sites. All municipal waste shall be collected from inhabitants of a given household, so taking waste to illegal dumping sites will no longer be beneficial to a household. Taking into account the low ecological awareness of some residents and a relative lack of generational responsibility for the natural environment, the economic factor may play a key role in persuading people to run a rational waste management system.

Among open comments given by respondents under "Any other problems," the most frequent are: mixing preselected waste when collected by authorized services (discussed above), inconsistency in waste collection fees or penalties for illegal disposal in woodlands in the territory of the studied area, as well as general disregard for the natural environment.

Nearly $50 \%$ of inhabitants assess the waste management of the Pobiedziska commune and the Municipal Services Company as being fairly satisfactory. This assessment is not very positive, especially in the view of the fact that almost $17 \%$ of the residents rate it as clearly bad, and only $6.3 \%$ as good. $27.4 \%$ believe it is simply well managed. In summary, the results show that the general feeling of the residents in respect to waste management in Pobiedziska is unsatisfactory or even poor (the viewpoint of two-thirds of those polled). The result reflects a general assessment of waste management in Poland from before the revolutionary changes in 2013, when the Waste Framework Directive was implemented [40].

\section{Conclusions}

Improper handling of waste causes many environmental problems [49-53]. With reference to the findings of our fieldwork, the key problem for the Pobiedziska and Pobiedziska rural area waste management system is illegal dumping sites, which result from incorrect system solutions applied by the municipality. More proof of this assumption is the results of the survey conducted among the residents, who believe that illegal dumping sites are the most essential environmental issue in terms of waste management. The problem is also recognized by the local authorities, who systematically request municipal services to eliminate the sites. It is hoped that new system solutions introduced in mid-2013 and the systematic improvement of ecological awareness of inhabitants (who are aware of this 
problem, which is evident from the survey) will contribute over time to complete elimination of the problem of illegal dumps. It is also absolutely indispensable to launch programs that raise ecological awareness within the local community and to provide better access to information about the environment for all inhabitants. This will improve the waste management system in Poland, adjust it to EU requirements stipulated in the Waste Framework Directive [40], and pave the way for meeting relevant Polish criteria.

The findings of this study are a good starting point for further studies that will determine whether the newly introduced system of waste management and consequential trends turn out to be correct in the long-term perspective. Further studies in this respect are planned for a few years after introducing the new system in hopes of determining whether the system has lived up to its promise.

\section{References}

1. PARYSEK J.J. Introduction to spatial management. Wydawnictwo Naukowe UAM, Poznań, 2006 [In Polish].

2. ROSIK-DULEWSKA C. Basics of Waste Management. PWN, Warszawa, 2015 [In Polish].

3. ŻYGADŁO M. Municipal Waste Management. Wyd. Politechniki Świętokrzyskiej, Kielce, 2002 [In Polish].

4. KOZŁOWSKA B., LASKOWSKA K. Analysis of the new waste management system in the context of sustainable development. In: P. Manczarski (Ed.), Integrated Waste Management, PZIiTS, Poznań, 77, 2015 [In Polish].

5. GÓRSKI M. Legal responsibility of municipalities and entrepreneurs in new systems for dealing with municipal waste. In: Integrated Waste Management. The first experience resulting from the implementation of the Waste Act, Abrys, Poznań, 12, 2013 [In Polish].

6. GRZYMAŁA Z., MAŚLOCH G., GOLEŃ M., GÓRNICKI E. Rationalisation of municipal waste management in Poland in the view of changes to the law on maintaining cleanliness and order in municipalities. Oficyna Wydawnicza SGH, Warszawa, 2013 [In Polish].

7. JAŚKIEWICZ P., OLEJNICZAK A. Municipal Waste Management in the Municipality. New rules functioning of the system in 2013. C.H. Beck, 2013 [In Polish].

8. BUJNY J. The functioning of selective collection systems on the example of municipalities and associations of municipalities. In: Selective collection, segregation and recycling of waste, Abrys, Poznań, 38, 2014 [In Polish].

9. GÓRSKI M. Legal aspects of municipal waste selective collection and the processing thereof. In: Selective collection, segregation and recycling of waste, Abrys, Poznań, 13, 2014 [In Polish].

10. MARCINKOWSKI T. (Ed.) Integrated Waste Management. PZIiTS, Poznań, 2009 [In Polish].

11. MARCINKOWSKI T. (Ed.) Integrated Waste Management. PZIiTS, Poznań, 2011 [In Polish].

12. MANCZARSKI P. (Ed.) Integrated Waste Management. PZIiTS, Poznań, 2013 [In Polish].

13. MANCZARSKI P. (Ed.) Integrated Waste Management. PZIiTS, Poznań, 2015 [In Polish].

14. BUCZYŃSKA A., CYPROWSKI M., SZADKOWSKASTAŃCZYK I. Indoor Disposal of Household Waste as a Source of Environmental Biohazard Exposure. Pol. J. Envi- ron. Stud., 20 (4), 851, 2011.

15. FALANDYSZ J., SZYMCZYK K. Data on the Manufacture, Use, Inventory and Disposal of Polychlorinated Biphenyls (PCBs) in Poland. Pol. J. Environ. Stud., 10 (3), 189, 2001.

16. ALTIN S., ALTIN A., ELEVLI B., CERIT O. Determination of Hospital Waste Composition and Disposal Methods: a Case Study. Pol. J. Environ. Stud., 12 (2), 251, 2003.

17. NARAYANA T. Municipal solid waste management in India: From waste disposal to recovery of resources?. Waste Manage., 29 (3), 1163, 2009.

18. MAGRINHOA., DIDELET F., SEMIAO V. Municipal solid waste disposal in Portugal. Waste Manage., 26 (12), 1477, 2006.

19. BRUNNER P.H., RECHBERGER H. Practical Handbook of Material Flow Analysis. CRC Press, Boca Raton, Florida, 2003.

20. TARR M.A. (Ed.) Chemical Degradation Methods for Wastes and Pollutants: Environmental and Industrial Applications. Marcel Dekker Inc., New York, 2003.

21. ÖZBAY I. Evaluation of Municipal Solid Waste Management Practices for an Industrialized City. Pol. J. Environ. Stud., 24 (2), 637, 2015.

22. MORRISSEY A.J., BROWNE J. Waste Management Models and their Application to Sustainable Waste Management. Waste Manage., 24 (3), 297, 2004.

23. CRAIGHILL A.L., POWELL J.C. Lifecycle assessment and economic evaluation of recycling: A case study. Resou. Conserv. Recycl., 17 (2), 75, 1996.

24. KADAFA A.A., ABD MANAF L., SULAIMAN W.N.A., ABDULLAH S.H. Applications of System Analysis Techniques in Solid Waste Management Assessment. Pol. J. Environ. Stud., 23 (4), 1061, 2014.

25. RAMEZANI L., ARJMANDI R., MOHARAMNEJAD N., MONAVARI S. M. Eco-Efficiency of Biowaste Management: Case Study of a Tehran Composting Operation. Pol. J. Environ. Stud., 24 (2), 665-673, 2015.

26. RIMAITYTÈ I., DENAFAS G., MARTUZEVICIUS D., KAVALIAUSKAS A. Energy and Environmental Indicators of Municipal Solid Waste Incineration: toward Selection of an Optimal Waste Management System. Pol. J. Environ. Stud., 19 (5), 989, 2010.

27. GENEROWICZ A. Multi-Criteria Analysis of Waste Management in Szczecin. Pol. J. Environ. Stud., 23 (1), 57, 2014.

28. BADGIE D., ABU SAMAH M.A.,ABD MANAF L., MUDA A.B. Assessment of Municipal Solid Waste Composition in Malaysia: Management, Practice, and Challenges, Pol. J. Environ. Stud., 21 (3), 539, 2012.

29. YENICE M.K., DOĞRUPARMAK S.C., DURMUŞOĞLU E., ÖZBAY B., ÖZ H.O. Solid Waste Characterization of Kocaeli. Pol. J. Environ. Stud., 20 (2), 479, 2011.

30. KOTOVICOVÁ J., TOMAN F., VAVERKOVÁ M., STEJSKAL B. Evaluation of Waste Landfills' Impact on the Environment Using Bioindicators. Pol. J. Environ. Stud., 20 (2), 371, 2011.

31. NYCZ-WRÓBEL J. Environmental awareness and the resulting risks to the environment (on the example of opinion of residents of the Podkarpackie Province). Zesz. Nauk. Pol. Rzesz., 286 (19), 63, 2012 [In Polish].

32. SAWIŃSKI Z., SZTABIŃSKI P.B., SZTABIŃSKI F. Interviewer handbook. SMG/KRC Poland Media, WIFiS PAN, Warszawa, 2000 [In Polish].

33. Pobiedziska Urban-Rural Commune Office. www. pobiedziska.pl. [Access 2.08.2015]

34. Pobiedziska Urban-Rural Commune Development Strategy 2012-2020. DGA, 2012 [In Polish]. 
35. National Waste Management Plan 2014. Monitor Polski, 101 (1183), 5270, 2010 [In Polish].

36. Local Data Bank of Central Statistical Office of Poland, www.stat.gov.pl [Access 2.08.2015].

37. Reports on implementation of waste management plan for the Pobiedziska Urban-Rural Commune. Urząd Miasta i Gminy w Pobiedziskach, Pobiedziska, 2007, 2009, 2011 [in Polish].

38. Public Information Bulletin of Pobiedziska Urban-Rural Commune. www.bip.pobiedziska.pl [Access 2.08.2015].

39. Disposal Program of Products Containing Asbestos from Pobiedziska Urban-Rural Commune. Am Trans Progres LLC, Poznań, 2014 [In Polish].

40. Waste Framework Directive, Directive 2008/98/EC of the European Parliament and of the Council of 19 November 2008 on Waste and Repealing Certain Directives. Official Journal of the European Union, 312, 3, 2008.

41. Waste Management Act. Dziennik Ustaw, 21 (1), 107, 2013 [In Polish].

42. FOLTYNOWICZ Z., KAPS R. Development of the polish system for plastic waste management vs. experiences in Austria. In: T. Marcinkowski (Ed.) Integrated Waste Management, PZIiTS, Poznań, 153, 2009 [In Polish].

43. Guidelines for maintaining the cleanliness and order in Pobiedziska Urban-Rural Commune, Resolution No. XL/491/06 of the Pobiedziska Urban-Rural Commune Council, 2006 [In Polish].

44. Strategy for the Development of Pobiedziska Urban-Rural Commune for the years 2012-2020. DGA, Pobiedziska, 2012 [In Polish].

45. Technical-technological and landform project of municipal- industrial wastes landfill in Pobiedziska Urban-Rural Commune. Technika Środowiska ARKA KONSORCJUM S.A., Poznań, 1995 [In Polish].

46. Wielkopolska Voivodship Waste Management Programme 2012-2017. Arcadis LLC, Katowice, 2012 [In Polish].

47. MICHAŁKIEWICZ M., PISKOREK J. Microbiological Air Pollution in Municipal Solid Waste Landfills. Rynek Instal., 11, 95, 2008 [In Polish].

48. Operational Guidelines for Landfill of non-hazardous and inert wastes in Borówko. Pobiedziska, 2009 [In Polish].

49. BRACH M., WIŚNIEWSKI M. Spatial Aspects of Illegal Dumping Sites of Municipal Wastes in the Stankowizna Forest Range. Rocz. Geomat., X 5 (55), 37, 2012 [In Polish].

50. CRITTO A., CARLON C., MARCOMINI A. Characterization of contaminated soil and groundwater surrounding an illegal landfill (S. Giuliano, Venice, Italy) by principal component analysis and kriging. Environ. Pollut., 122 (2), 235, 2003.

51. KASZUBKIEWICZ J., GAŁKA B., KAWAŁKO D. Impact of Legal and Illegal Waste Dumps on the Surrounding Soils in the Jelenia Gora and Wrocław Districts. Rocz. Glebozn., LXII (2), 179, 2011 [In Polish].

52. SOBIK K. Study on the impact of landfills on soil and water environment based on selected objects located in the catchment of the Dunajec. PhD Dissertation, Kraków, 2007 [In Polish].

53. KOZŁOWSKAB. The consequences of incorrect application of the waste hierarchy. In: Integrated Waste Management. The first experience resulting from the implementation of the Waste Act, Abrys, Poznań, 112, 2013 [In Polish]. 